\title{
FOREIGN BANK OWNERSHIP \\ AND BUSINESS CYCLE SYNCHRONIZATION IN THE EUROPEAN UNION
}

In this article the impact of foreign bank ownership on the synchronization of business cycles between the euro area and EU countries is analysed with the use of data for $28 \mathrm{EU}$ member states from 1998 to 2016 . The main finding is that economies with a higher share of assets owned by foreign banks are more cyclically synchronized with the euro area which is chiefly the result of greater alignment in investment cycles. It suggests that foreign banks, originated mainly in other EU member states, treat host countries largely as an extension of their domestic markets, and their lending behaviour at home and in the host countries is similar. Our results show that greater foreign bank ownership reduces the costs of European monetary integration.

Keywords: bank ownership, optimum currency area, business cycle synchronization

JEL Classifications: E32, E44, F36, G32, F45

DOI: $10.15611 /$ aoe.2020.1.02

\section{INTRODUCTION}

Since the 1990s, financial globalization has brought about significant changes in bank ownership structures in both developing and high-income countries. In the former, the average asset share of foreign owned banks peaked at $50 \%$ in 2008 , whereas in the latter it reached the local maximum of $43 \%$ in the same year (Cull et al., 2017). The outbreak of global financial crises (GFC) reversed the trend towards higher share of assets owned by foreign banks. The drivers functioning so far, of greater foreign ownership, such as financial liberalization and privatization have abated, and criticism towards government bank ownership has subsided. Many economists voiced concerns that foreign banks amplify the negative impact of global shocks on the domestic economy thus offsetting the widely postulated benefits of

\footnotetext{
* Department of Economics II, Warsaw School of Economics.

${ }^{* *}$ Faculty of Economics and Sociology, University of Lodz.

*** Warsaw School of Economics.
} 
foreign bank ownership, such as increased capital and lending capacity, know-how transfer, innovations and greater competition (Demirgüç-Kunt et al., 1998; Goldberg, 2004; Lee et al., 2012).

The typical approach to the issue of bank ownership is to examine the impact of foreign (or government) ownership in three dimensions: competition in the banking sector, financial stability, and credit supply. In this study the authors propose a different approach, putting the bank ownership into the context of the synchronization of business cycles and monetary integration. The paper poses the following question: does the bank ownership structure influence the convergence of business cycles between countries making up a monetary union, and if so, in which direction? The authors believe this question is motivated by two observations. First, the average asset share of foreign owned banks in the EU member states is close to $50 \%$ (see Table 1 in the Annex) and many EU countries hold large stakes in domestic banking sectors. Whether or not to increase foreign ownership in the banking sector by privatizing these banks or take different routes (status quo, greater domestic private ownership) pose a dilemma for policymakers, which can be more easily addressed once the impact of greater foreign ownership in the banking sector on co-movement of economic activity is known. Second, in recent years some EU member states (Poland and Hungary) have decided to adopt the 'seize-the-opportunity' strategy aimed at increasing their governments' stakes in their banking sectors by buying banks from foreign owners. The strategy of domesticating the foreign-owned banks was presented as a way to achieve a more independent cycle of domestic credit and demand in the time of global economic shocks. Whether this strategy leads to the de-synchronization of business cycles between these countries and thus higher costs of monetary integration is an empirical question.

To the best of the authors' knowledge, the bank ownership structure has not been analyzed yet as a determinant of business cycle alignment in the context of European integration. Several authors have addressed the impact of financial integration on the co-movement of economic activity (CesaBianchi et al., 2016; Duval et al., 2015; Kalemli-Ozcan et al., 2010). They all used statistical data released by the Bank for International Settlements (BIS) to calculate various measures of bilateral bank linkages based on banks' international financial claims and liabilities, thus keeping the bank ownership structure out of the spotlight.

The only paper known to the authors that explicitly addressed the nexus between bank ownership and business cycle synchronization is by Morgan 
et al. (2003). They showed that a greater share of total bank assets in individual US states owned by bank holding companies that also hold banking assets in other states, leads to the stronger alignment of business cycles between states. These findings, however, have only limited applicability for the EU member states as they substantially differ from the US states in two important aspects. First, despite the existence of the EU single market and the concomitant harmonization of the legal framework in the area of the four economic freedoms, global banks face nevertheless different regulatory regimes in individual EU member states that may change in an idiosyncratic way in the aftermath of economic shocks. Second, the degree of fiscal policy coordination among EU member states is substantially lower than in the US where federal fiscal transfers are used to smooth the business cycle. As a result, fiscal policy response to shocks is likely to differ between EU countries. Both factors create an additional source of uncertainty which may prompt international banking groups to change lending levels in host countries relatively strongly compared to domestic lending levels. This suggests that the link between bank ownership and the convergence of business cycles in the European Union deserves special focus.

The authors used the model of business cycle synchronicity developed by Fidrmuc (2001) in order to test the impact of foreign bank ownership on cyclical convergence between the euro area and EU member states. The study used data on the asset share of foreign-owned banks in 28 member states for 1998-2016. For the majority of countries, this dataset embraces the period both before and after GFC. The findings allow to expand the discussion on the costs of monetary integration resulting from abandoning domestic monetary policy that can be used to smooth the business cycle in times of asymmetric shocks. These results should be particularly relevant for new EU member states from Central and Eastern Europe (CEE), which have either joined the euro area (Slovakia, Slovenia, the Baltic countries) or have so far refrained from introducing the euro (the Czech Republic, Hungary, Poland, the Balkan countries). All these countries allowed for a massive increase in the asset share of foreign-owned banks in the post-communist transition period.

The remainder of the paper is organized as follows. Section 2 discusses determinants of business cycles and their synchronization. Section 3 discusses the impact of bank ownership on the business cycle and presents the hypothesis to be tested. Section 4 presents a model of cyclical convergence and the dataset of additional regressors. Section 5 shows the estimation method and discusses the results, and Section 6 contains sensitivity analysis. Finally, Section 7 concludes. 


\section{DETERMINANTS OF BUSINESS CYCLES AND THEIR SYNCHRONIZATION}

Since the work of J. M. Keynes (1936), fluctuations in investment activity are treated as the main cause of cyclical increases and decreases of GDP growth. However, the determinants of this fluctuations are largely disputed in the literature and spread from exogenous factors like "animal spirits that drive the decisions of investors and managers" (Keynes, 1936; Akerlof and Shiller, 2009), lags between investment plans and actual investment outlays (Kalecki, 1990), political election cycles (Drazen, 2000), and even stochastic sun-spot-type technological shocks (King et al., 1987) to endogenous factors - changes in productivity (Holland and Scott, 1998), movements of inventories (Zarnowitz, 1999), economic policy stance, especially the one pursued by the central bank (Cotis and Coppel, 2005), asset price fluctuations (IMF, 2000) and financial openness (Buch et al., 2002). From the viewpoint of this article, the most important drivers of business cycles are those connected to financial markets that induce changes in the availability of capital to corporate and private investors. This is in line with the approach presented by Zarnowitz (1999) who argues that at the centre of business cycles are interacting movements in investment and credit whose swings are cumulative and mutually reinforcing. These factors can be aggregated into two groups - those affecting corporate credit and those affecting mortgage lending, and imposing house price fluctuations. The former can be explained by referring to the Keynes-Minsky cycle approach (Fazzari et al., 2008). In Minsky's theory (1992), investment is financed through internally generated cash flows and external debt - if cash flow is insufficient to finance investment, firms take on debt. As, according to Keynes (1936), cash flows are endogenous and dependent on nominal interest rates and debt-to-income ratios, one gets a business cycle in which companies take on debt in times of boom which causes an increase in nominal interest rates, hampering cash flows and eventually investment activity, which then leads to a bust. Such a cycle can be either amplified or dampened by monetary and macroprudential policy as well as international cash flows that impact nominal interest rates and corporate credit availability.

Much better established in the mainstream economy is the line of research that follows the nexus between mortgage credit, housing investment and general economic activity. As Leamer boldly stated, "housing is the business cycle" (2015:1). He argues that the housing sector is so deeply 
embedded, both in the real economy and in the financial market, that any large fluctuations in residential estate prices and demand cause large changes in global output. Moreover, a high dependence of the real economy, especially the construction sector, on house prices and housing market structure has been proved for the majority of developed countries (Davis and Heathcote, 2005; Cardarelli et al., 2009; Czerniak and Rubaszek, 2018).

The interdependence of housing market fluctuations and the financial sector in the context of business cycles has been also largely investigated (Classens et al., 2009; Feldstein, 2007; Gjerstad, Smith, 2010; André and Girouard, 2008; Cardarelli et al., 2009). Out of this vast research agenda three outcomes of that relation come to the fore. The most important one is the financial acceleration mechanism described by Bernanke et al. (1999), describing a recursive relation between house prices and credit supply which can amplify business cycle fluctuations. In times of a housing boom the prices of real estate rise which increases the value of mortgage credit collaterals. This in turn translates into the higher willingness of banks to finance house purchases, leading eventually to the further growth of housing demand and prices. Moreover, that very same mechanism also boosts consumption growth, as part of private spending is financed by mortgagebacked consumer loans and subject to the so-called wealth effect, i.e. an increase in the propensity to consume caused by the growth of household wealth in the form of the higher real estate value (Catte et al., 2004).

The second important factor that impacts the relation between the financial sector and housing market fluctuations are international capital flows. As already widely discussed (Buch et al., 2002), financial openness can amplify or dampen the reaction of a small open economy to idiosyncratic shocks depending on the character of that shock. In the case of housing investment, a boom in the real estate sector usually attracts foreign capital, leading to a further increase in the demand for housing. As a result, in the case of asset market imbalances, financial openness and international capital flows can increase business cycle fluctuations (Gjerstad and Smith, 2010). Moreover, as theoretical research shows (Brzoza-Brzezina et al., 2018), the foreign ownership of banks amplifies spillovers from external shocks through trans-border capital flows.

The last important line of research is the one that investigates the linkage between housing and business cycles in the context of the financial market structure - its regulations, mortgage finance systems and general institutional embeddedness (IMF, 2008). It is argued that more flexible and developed mortgage markets amplify the impact of monetary policy on 
house prices and thus, ultimately, on consumer spending and output (Calza et al., 2007).

There has been a long-standing interest in identifying the drivers of business cycle synchronization between economies. The first and most frequently quoted determinant of co-movement in business cycles is bilateral trade. Empirical studies suggest that countries that trade more exhibit higher synchronicity of business cycles (Frankel and Rose, 1998; Clark and van Wincoop, 2001). Whether this synchronicity is sustainable depends on specialisation patterns. Countries that trade more with similar goods (intraindustry trade) are less exposed to asymmetric shocks and tend to have greater synchronisation of business cycles (Fidrmuc, 2001). By the same token, economies with more similar industrial structures or, more broadly, similar structural characteristics, are likely to be more synchronous (Calderon et al., 2007; Imbs, 2004, 2006; Karadimitropoulou, 2018). Interestingly, trade works as a transmission channel not only for demand shocks but also for technology shocks, as higher bilateral trade intensity is associated with stronger TFP correlations (Juvenal et al., 2017).

Globalization and the concomitant emergence of global value chains have become an impulse for a new strand of research focusing on trade in intermediate inputs as a determinant of business cycle synchronization. Di Giovanni and Levchenko (2010) point towards the increased convergence of business cycles in cross-border industry pairs that use each other as intermediate inputs (vertical linkages). Cuñat and Zymek (2017) provide evidence that countries with a similar intermediate goods content of exports are likely to exhibit greater correlation of GDP fluctuations. Jeon (2018) avoids double-counting by using value-added trade data to find that for European countries the link between trade and business cycle co-movements is more clearly observed when value-added data are used.

The second driver of business cycle co-movements is financial integration. Countries that are financially integrated should exhibit greater synchronization of economic activity driven by capital flows than countries in which capital mobility is constrained (Cerqueira and Martins, 2009). Empirical evidence generally suggests that more financially integrated economies are more cyclically converged (Imbs, 2004, 2006; Kose et al., 2003) and financial openness of the shock-receiving country amplifies the spillover of business cycles (Montinari and Stracca, 2016). However, the latter contribution brings mixed results as bilateral financial links are mostly insignificant as a driver of business cycle synchronization and are signed negatively when statistically significant. 


\section{FOREIGN BANK OWNERSHIP AND BUSINESS CYCLE}

The existing literature suggests that foreign bank ownership can affect the business cycle via two channels. The first conduit is the impact on domestic banking sector stability or, if a wider perspective is applied, on financial sector stability. The second channel is the impact on access of economic agents to bank credit. In both areas, foreign banks can exert a stabilizing or destabilizing effect on the domestic economy, and whether the former or the latter effect prevails has been the subject of numerous empirical studies.

The impact of foreign bank ownership on banking sector stability depends on the source of the shocks hitting the domestic economy. It is generally assumed that in the case of domestic shocks foreign banks can stabilize the domestic economy. Large international banking groups conduct diversified operations in many markets, and even a large shock originating in one country is unlikely to significantly affect their overall capital base and liquidity position. Therefore, despite the shock, subsidiary banks can tap liquidity or capital provided by their owner and continue to supply credit to the domestic economy. Global or home-country shocks, however, can prompt foreign banks to reduce funding to their subsidiaries and branches. Studies by Cetorelli and Goldberg (2012a, 2012b, 2012c) show that globally active banks link markets by managing liquidity across the entire banking organization. Once hit by a funding shock, they are likely to reallocate liquidity in a way that buffers shocks to the parent bank balance sheets.

Empirical studies tend to confirm that sources of disturbances determine the reaction of foreign banks to shocks. De Haas and Van Lelyveld (2006, 2010) applied panel data analysis for the bank-level data and found that in the CEE countries, domestic banks contracted their credit base during crisis periods whereas greenfield foreign banks, benefiting from parental support, did not. Bank-level data across a broad section of countries were also used by Demirguc-Kunt et al. (1998) to show that higher foreign bank participation lowers the probability that a country will experience a banking crisis. Studies focusing on home country shocks, however, show that foreign bank ownership may act as an amplifier of external disturbances. Such behaviour of foreign banks was observed in Peru after the 1998 Russian default and the concomitant negative liquidity shock to international banks (Schnabl, 2012). In the US, the banks affected by the Russian default reduced levels of lending and raised loan interest rates significantly more than the unaffected banks (Chava and Purnanandam, 2011).

Empirical research points to the existence of the world business cycle driven by "animal spirits" (De Grauwe andYuemei, 2017), volatility in trade 
and industrial activity (Lumsdaine and Prasad, 2003) or changes in commodity prices (Fernández et al., 2017). It suggests that the frequency and impact of global shocks via foreign bank ownership is likely to remain significant. The evidence on the behaviour of foreign-owned banks on the basis of postGFC data is thus highly relevant. The general conclusion that can be drawn from the post-GFC studies for the UK, Russia and a broad section of other countries is that in times of global and large shocks, foreign banks tend to reduce lending at a greater pace than their host competitors (i.e. domestic banks) (Aiyar, 2012; Fungáčová et al., 2013; de Haas and van Lelyveld, 2014). The evidence for Central and Eastern Europe and the emerging European countries is, however, somewhat less compelling. Choi et al. (2016) provided evidence for GFC-driven reduced lending by foreign-owned banks in CEE countries. De Haas et al. (2015), on the contrary, showed that western European banks participating in the Vienna Initiative were relatively stable lenders during the Great Recession.

The domestic business cycle can also be affected via the second aforementioned channel, i.e. access to credit. It is frequently argued that foreign banks face information asymmetry compared with local banks. Domestic banks frequently use 'soft information' in order to evaluate the creditworthiness of domestic informationally opaque borrowers (relationship lending - Cull et al., 2017). This information is hardly available to foreign banks which rely to a greater extent on 'hard information' such as financial statements or credit history (transaction lending). Bolton et al. (2016) developed a model in which relationship banks charge higher intermediation spreads in normal times than transaction banks. In times of a downturn, however, relationship banks continue to lend to profitable firms at terms that are more attractive than those offered by transaction banks. This suggests that foreign banks focusing on transactional lending are likely to magnify output fluctuations during economic slowdown.

However, empirical research on the procyclicality of lending by foreign banks is not unequivocal. Beck et al. (2014) showed that relationship lending alleviates credit constraints during cyclical downturns and this effect is strongest for smaller and more informationally opaque firms and regions affected by a more severe slowdown. Bonin and Louie (2017) take a somewhat different view. They suggested that foreign (transaction) banks are capable of building strong relationships with their local clients, which supports lending in the time of slowdown. They showed that during GFC in the countries of emerging Europe the lending behaviour of subsidiaries of the "Big 6" European multinational banks was not different from that of 
domestic banks. Their conclusion was that the "Big 6" treated the region as a "second home market".

The empirical evidence on foreign banks acting as amplifiers of economic disturbances transmitted via the two channels analysed above remains inconclusive. Given the rising significance of the global business cycle as a source of economic fluctuations observed at country level, the authors conjecture that increasing the asset share of foreign-owned banks leads to a stronger reduction in lending in times of a downturn and the desynchronization of business cycles between economies with significantly different shares of foreign ownership. The study tests this hypothesis for the economies of the euro area and $28 \mathrm{EU}$ member states, which differ markedly in foreign bank ownership, and which for many of them, especially CEE countries, is much larger than the average for the common currency area (see Table 1 in the Annex).

\section{DATA}

Below the authors describe the dependent and explanatory variables used in the estimation of the model (all the relevant data and the estimation results are presented in the Annex).

\subsection{Dependent variable: correlation of business cycle}

A simple and common (Fidrmuc, 2001) method was used to measure business cycle correlation $b c c$, i.e. the index of correlation of detrended indicator of economic activity (fourth differences of logs). In order to analyse panel data, so also to assess the relationship between changes in bank ownership and cyclical convergence, it was necessary to construct a moving index of correlation. Balancing the profits of taking a longer time series to have a more precise measure of real business cycle correlation with the costs of reducing the degrees of freedom for econometric parameter estimation, the authors decided to use a 12-quarter index of correlation, as this nowadays is equal to approximately half of a full business cycle.

The reference estimation used the seasonally and calendar adjusted ${ }^{1}$ real GDP chain-linked volumes in euros computed in line with ESA 2010 guidelines $^{2}$ with a quarterly frequency. Hence, the reference $b c c$ index was

\footnotetext{
${ }^{1}$ Only for Slovakia the seasonally and calendar adjusted data were not available, hence the authors used only seasonally adjusted values for real GDP.

${ }^{2}$ The data for each time series comes from the Eurostat database, if not stated otherwise.
} 
calculated as a 12-quarter moving-correlation for each EU member state (EU28) and the initial 12 euro area funding members. The sensitivity analysis also used the correlation index for an altered definition of the Eurozone (19 current euro area members), as well as the correlation indices for quarterly, seasonally and calendar adjusted chain-linked volumes in euros data ${ }^{1}$ on private consumption expenditures (ESA 2010 standard), gross fixed capital formation, also broken down into outlays on dwellings, other buildings and structures, transport equipment and other machinery and equipment (ESA 2010 standard) $^{3}$, level of unemployment (from the LFS survey), and finally monthly seasonally adjusted data for the European Sentiment Indicator (as compiled by the European Commission) between each EU member state and the 12 euro area founding members.

\subsection{Asset share of foreign-owned banks}

In order to construct the series on the asset share of foreign-owned banks (ownership) the study used the data published in various ECB reports "EU banking structures" (November 2004, October 2006, September 2010) and ECB "Report on financial structures" (October 2017). The share of assets owned by foreign banks was calculated as the share of assets of subsidiaries and branches from other EU and third countries (i.e. foreign owners holding directly or indirectly at least $50 \%$ of the bank's shares) in total assets of credit institutions. The authors obtained several series and some missing observations from EU central banks and institutions of financial supervision.

\subsection{Intensity of intra-industry trade}

The authors used a common measure of intra-industry trade intensity, namely the Grubel-Lloyd index (Grubel and Lloyd, 1975), defined as:

$$
I I T_{r}=100\left(1-\frac{\sum_{i=1}^{n}\left|X_{r i}-M_{r i}\right|}{\sum_{i=1}^{n}\left(X_{r i}+M_{r i}\right)}\right),
$$

where $X_{r i}$ is exports of product group $i$ from country $r$ to euro area countries, and $M_{r i}$-imports of product group $i$ to country $r$ from the euro

\footnotetext{
${ }^{3}$ Data on gross fixed capital formation were unavailable for Croatia. For Belgium, Poland, Hungary and Romania the quarterly time series by asset type were interpolated from available real annual data by asset type with the use of quarterly structure of total gross fixed capital formation seasonally and calendar adjusted chain-linked volumes in euros.
} 
area. If country $r$ itself belongs to the euro area, $G L$ index calculation uses values of exports and imports of that country with the rest of the euro area. The $I I T_{r}$ index ranges from 0 to 100 , with 0 indicating that all trade between country $r$ and the euro area is inter-industry only (i.e. exports and imports never occur both within the same product group), while 100 is the case of fully intra-industry trade (i.e. when exports equals imports in each product group).

To calculate the IIT index the study used annual data on international trade in goods since 1988, in current prices (euros), according to Harmonized Commodity Description and Coding Systems (HS) at the "chapters" level, comprising 97 commodity groups. The IIT index was calculated for all EU member states (EU28), in two variants, dependent on the scope of euro area definition:

- for the original euro area comprising 12 countries,

- for the current euro area comprising 19 countries.

Note that the calculation is not limited to the years in which the euro area actually existed in a given shape, rather, when referring to "trade with the euro area", the authors mean trade with the respective group of countries (in either of the two variants listed).

In most cases, trade data covered the period 1988-2016. The following limitations apply: (i) until 1990 the data for Germany relate to West Germany only; (ii) calculation of trade with the 19 euro area members does not include Estonia, Lithuania, Latvia, Slovenia and Slovakia in the first years of the sample, as those countries did not yet exist as independent states. However, the latter simplification poses only a minor bias on the calculated IIT indices, as the share of the mentioned countries in the total trade turnover of the 19 euro area countries was very small (it amounted to only $1.3 \%$ in 1993 , although increasing in further years).

\subsection{Trade openness indicators}

In addition to the IIT index, the following general measures of economic trade openness were used:

$$
\begin{gathered}
E S_{r}=100 \frac{E_{r}}{G D P_{r}}, \\
T S_{r}=100 \frac{E_{r}+M_{r}}{G D P_{r}},
\end{gathered}
$$


where $E S_{r}$ denotes the share of exports to the euro area in the GDP of the reporting country $r$, and $T S_{r}$ denotes the share of exports to, plus imports from, the euro area in the GDP of the reporting country $r$ (all variables in current prices). Similarly to the IIT index, the authors calculated two variants of ES and TS shares, depending on the scope of the euro area (12 versus 19 members); the same Eurostat data were used for the IIT index computation. Accordingly, exports and imports only comprise goods, not services. The same data limitations apply. An additional limitation is related to the switch from ESA 1995 to ESA 2010 - only a few countries had their GDP estimates revised for the period before 1995. Therefore the study used ESA 2010 GDP data from 1995 onwards, while before 1995 the ESA 1995 based estimates were used for all countries. Consequently, there is a structural change in the resulting openness indicators in 1995, but it applies to all countries.

\subsection{Additional control variables}

Apart from the above described variables the authors also used several control variables that serve as predetermined variables in the GMM estimation procedure (see Section 4 for econometric modelling description). The first of them is the economic convergence level conv between a given member state and the most developed EU countries, as measured by the percentage difference between annual GDP per capita in PPS terms in the analyzed state and the average for the three best EU performers for the year of computation.

The second control variable is the specialization index spec that measures the similarity of industrial production in manufacturing. Following KalemliOzcan et al. (2013), the authors calculated this index using the following formula, where $s_{i, t}^{n}$ and $s_{e z, t}^{n}$ denote the GDP share of manufacturing industry $n$ in year $t$ in country $i$ and the Eurozone (ez), respectively:

$$
S P E C_{i, t} \equiv \sum_{n=1}^{N}\left|s_{i, t}^{n}-s_{e z, t}^{n}\right| .
$$

The third control variable is the importance of a given country for the whole EU economy (share), measured as the share of its nominal GDP in the GDP level for the group of 28 European Union countries for each year of the analysis. Additionally, the authors also controlled for Eurozone membership (eurozone) and the date of EU accession (E_union) using a dummy panel 
variable that takes the value of 1 if a given country in a given year is a member of the euro area or the European Union, respectively, and the value of 0 otherwise. Moreover, to assess the institutional environment of the financial market the study used the model of capitalism classification proposed by Czerniak and Rapacki (2018), based on which the authors introduced a dummy panel variable that takes the value of 1 for countries that were identified as those that exhibit a market-based model of financial intermediation, and the value of 0 otherwise. Finally, the last control variable PIL reflects the extent of integration of a given country with the global financial markets. To measure this variable the authors used the ratio between a country's portfolio investment liabilities (taken from its end-ofperiod international investment position), and its nominal GDP level for each year of the analysis.

\section{ESTIMATION RESULTS}

This empirical research method is based on the approach of Fidrmuc (2001) who tested the impact of trade integration on business cycle synchronization, for which he used variants of the following model specification:

$$
\operatorname{Corr}\left(Q_{i}, Q_{j}\right)=\alpha+\beta \log \left(T I_{i j}\right)+\gamma I I T_{i j},
$$

where $\operatorname{Corr}\left(Q_{i}, Q_{j}\right)$ is the correlation index of detrended indicators of economic activity (GDP or industrial output) between countries $i$ and $j$; $T I_{i j}$ measures bilateral trade intensity (trade integration) between countries $i$ and $j$, defined as $T I_{i j}=T_{i j} /\left(T_{i}+T_{j}\right)$ where $T$ represents exports, imports or total trade volume; $I I T_{i j}$ is the Grubel-Lloyd index of intra-industry trade. Due to the possible endogeneity of trade intensity indicators (adoption of common currency, reinforced by business cycle synchronization, might in turn induce bilateral trade), the model's parameters were estimated with the use of the instrumental variables method. This estimation was also supplemented by sensitivity analysis, in which the reference specification was augmented by additional variables, including the dummies indicating euro area membership and bilateral differences in GDP levels.

The authors decided to use panel data instead of pure cross-country data in order to also cover the changes in business cycle synchronization from the EU integration period up to the aftermath of the global financial crisis. 
Hence it was necessary to slightly alter the econometric method and the model specification compared to the Fidrmuc approach, i.e. estimating the following regression:

$$
\operatorname{Corr}_{t}\left(E Z, Q_{j}\right)=\alpha+\alpha_{0} \operatorname{Corr}_{t-1}\left(E Z, Q_{j}\right)+\beta T S_{t j}+\gamma I I T_{t j}+\text { Oownership }_{t j},
$$

where $\operatorname{Corr}_{t}\left(E Z, Q_{j}\right)$ is the correlation in the last 12 quarters of detrended indicators of economic activity (GDP in the reference model) between the Eurozone (consisting of 12 initial members in the reference model) and country $j$ for year $t$; $T S_{t j}$ measures bilateral trade intensity (trade integration) between the Eurozone and country $j$ in year $t$; IIT $T_{t j}$ is the GrubelLloyd index of intra-industry trade in period $t$ and ownership $p_{t j}$ is the share of foreign-owned institutions in banking assets of country $j$ in period $t$ (for data description see Section 3).

To estimate the parameters of this regression, the study used the GMM Arellano-Bover procedure (Arellano and Bover, 1995) with predetermined regressors (i.e. these are not included in the differenced equation estimation) and robust estimators of standard errors. For sensitivity analysis of the obtained parameters the authors altered the above model specification by using different economic activity measures for the dependent variable and by interchanging the specification of the bilateral trade intensity measure (see Section 3 for data description). The panel data used in the estimation procedure cover all $28 \mathrm{EU}$ countries for the time period 1998-2016, and is highly balanced ${ }^{4}$.

The basic estimation results are presented in Table 4 in the Annex and indicate that business cycle synchronization depends positively and significantly on intra-industry trade integration (which confirms the results obtained by Fidrmuc) and on foreign ownership of banks, i.e. the higher the share of foreign-owned institutions in banking assets for a given EU member state, the stronger the business cycle synchronization between this country and the Eurozone. These results are largely independent of the exact model specification (compare columns 1 to 4 in Table 4), however when one adds the control variable reflecting the relative size of a member state's economy

\footnotetext{
${ }^{4}$ There are some missing observations mainly for the ownership variable and the PIL control variable. In the case of different specifications of the dependent variable there are some data missing for the ESI indicator and unemployment. It was decided not to extrapolate the publicly available set of indicators so as to minimize the estimation errors connected to the methodological incoherence of the data.
} 
(EU_share) the ownership variable loses on statistical significance. The authors attribute this to possible correlations between control variables as the

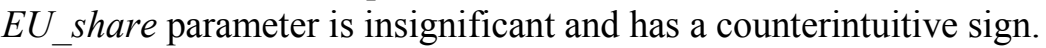

It is important to note that the importance of trade integration is weaker than in the modelling experiment presented by Fidrmuc. Moreover, also trade intensity is less significant in explaining business cycle correlation than suggested by Fidrmuc - in some alternative model specifications with more control variables (see columns 3 to 6 in Table 4), the $T S$ variable, measuring both export and import intensity, exhibits weak statistical significance.

Out of the six additional control variables only two are important determinants of the dependent variable. Firstly, economic convergence conv between a given country and the euro area displays a positive correlation with GDP fluctuations, i.e. the smaller the difference between a country's development level and that of the best EU performers the higher the synchronization of business cycles. Secondly, the more international portfolio investment liabilities PIL a country reports (e.g. larger share of foreign investors in the debt or equity markets, more trade credits from nonresident contractors), the less in unison this country is with the rest of the euro area economy. This means that the larger financial integration of a given country with global markets through 'hot money' inflows (excluding FDI investments in the banking sector) reduces its synchronization with the Eurozone.

The four remaining control variables (EUshare which measures the relative size of each EU economy, eurozone that indicates which country is a member of the European Currency Area, E_union taking into account EU membership and spec index reflecting manufacturing specialization of a given economy) do not exhibit any significant relationship with business cycle synchronization. Hence they are excluded from further estimations. Nevertheless, one might notice that all the estimated parameters but one (EUshare) have the expected sign - Eurozone and EU membership increases the business cycle synchronization and differences in manufacturing specialization diminishes it.

\section{SENSITIVITY ANALYSIS}

To test the robustness of the results, the authors analysed estimates' statistics of the initial model specification with significant control variables for alternative measures of the regressor (see Table 5 in the Annex). Firstly, the study analysed to what extent the alteration of euro area definition 
changes our findings; for that the authors decided not only to change the measure of business cycle correlation but also the general and intra-industry trade integration variables, so that they reflect the interdependence between a given country and the common currency area covering the actual 19 member economies instead of the initial 12 , as in this reference model. It was found (cf. column 1 and 2 in Table 5) that the alteration of the Eurozone definition slightly weakens the influence of the independent variables on business cycle synchronization, as indicated by the larger robust $p$-values for parameter estimates. This might be connected to the fact that enlarging the euro area makes it less homogeneous and hence the correlation in GDP changes is not a robust measure of business cycle synchronization.

Then the authors estimated the equation for alternative dependent variables, i.e. the correlation of different investment activities (gross fixed capital formation $G F C F$ by asset type) and private consumption fluctuations between EU members and the $12 \mathrm{EU}$ founders. The obtained estimation results (cf. columns 3 and 8 in Table 5) indicate that the foreign ownership of banks is of much bigger importance for the investment cycle synchronization than for consumption cycle synchronization. This, on the one hand, stems from the smaller fluctuations of private spending that reduce on average the correlation index and, on the other, from the higher importance of bank credit for investments than for consumption expenditures. The relationship between bank ownership and the synchronization of expenditures on other buildings and structures (excluding dwellings) among EU members is particularly strong. This indicates that bank groups tend to unify their credit policy for private companies across EU borders, but diversify the access to mortgage loans for households. This observation is further strengthened by the fact that the level of convergence is unimportant for commercial real estate investment cycle synchronization. This might be a result of the more unified macroprudential regulations in the EU's corporate credit market than in the mortgage segment. Similarly, the authorsfound a lesser importance of the ownership structure in the banking sector for the synchronization of labour market cycles as measured by correlations of unemployment fluctuations (see column 9 in Table 5). This may be explained by the largely differing labour market policies followed in the individual EU member states.

To test for the importance of institutional factors which determine the financial market structure in EU countries, the study drew on the classification of models of capitalism proposed by Czerniak and Rapacki (2018). They argue that one can find only two modes of financial intermediation in 
the EU - a market-based model, typical for the UK, Sweden, the Netherlands, Denmark and Spain, in which regulations and informal institutions promote to a wider extent financing through debt, and a bankbased model (most pronounced in Germany) in which capital for business activity is almost solely acquired through the banking system. For obvious reasons such institutional embeddedness might affect the importance of bank ownership for business cycle synchronization. However, the inclusion into this model of a dummy variable (market_b) that discriminates between those two different modes of financial intermediation does not influence the obtained parameters' estimations, and the variable itself is a statistically insignificant determinant of the correlation in economic fluctuations between countries.

Another important factor that might influence the impact of bank ownership structure on lending practices is the diversity of financial supervision and transnational regulations across the European Union. Since the global financial crisis several actions were undertaken to increase the negative external effects of transnational capital flows. They materialized in the form of the EU banking union, which consisted of two main initiatives, namely the Single Supervision Mechanism (operational since 2014) and the Single Resolution Mechanism, which fully entered into force in 2016. However, until the end of the time series sample only Eurozone members were covered by these two initiatives. Hence, if that transnational supervision mechanisms had any influence on the parameter estimates of the model one should have seen it in the statistical significance of the eurozone dummy variable, which - as stated above - was found an unimportant determinant of business cycle synchronization.

The last important feature of financial market structures in different EU countries is the size and share of shadow banking. As this is not directly included in the analysis, it might affect the obtained results and be an omitted factor in the analysis. However, according to ESRB (2018) analysis shadow banking activity is mainly concentrated in those Eurozone countries that already have a strong domestically-owned banking sector. In countries outside the euro area, especially NMS, where the share of foreign-owned banks is high, the importance of shadow banking for financing the economy is very low and concentrated mainly in the consumer credit sector. Moreover, shadow banking in a broad sense is very interconnected to the banking sector itself and usually its activity is highly coordinated with the credit strategy of the banks themselves. This leads to the conclusion that the role of shadow banking in financing the economy is indirectly included in 
the specification of the model and does not have any important impact on the parameters' estimates.

The authors also analysed the determinants of economic sentiment synchronization as measured by the European ESI indicators correlation. In comparison to the reference model, the estimated parameters do not largely differ (compare columns 1 and 10 in Table 5) - on the one hand the autoregressive component, intra-trade integration, economic convergence and trade intensity are slightly more important for explaining the changes in economic sentiment synchronization and, on the other, bank ownership and portfolio investment position exhibit slightly smaller $p$-values. Summing up, the results obtained strongly indicate that the ownership structure of banking assets is an important determinant of business cycle synchronization, especially while taking into account changes in investment outlays.

Given the lack of data on the country origin of the capital in the EU banking sector (outside-the-EU capital versus capital originating from EU member states), the authors were unable to test whether the structure of foreign capital has an impact on the synchronization of business cycles between EU member states and the euro area. It was beyond the authors' capability to analyse this structure for every EU bank, not to mention the objective difficulty to track down the country origin of listed EU banks' capital with large shareholder diversification and significant free float. Nevertheless, the data provided by the European Banking Federation suggest that the EU banking system is dominated by domestic credit institutions (European Banking Federation, 2018). In 2017 there were 6250 credit institutions in $28 \mathrm{EU}$ member states, out of which $85 \%$ were credit institutions legally incorporated in the reporting country, 9\% were the branches of euro area-based credit institutions, 4\% were the branches of EEA-based credit institutions (outside the euro area) and only $2 \%$ were branches of non-EEA based banks. Therefore, it can plausibly be assumed that in the EU member states the asset share of foreign-owned banks is strongly and positively correlated with the asset share of banks originating from other EU member states.

\section{CONCLUSIONS}

The authors used panel analysis to test whether increasing asset share of foreign-owned banks leads to the de-synchronization of business cycles between the euro area and $28 \mathrm{EU}$ member states. The analysis covered the 
period 1998-2016 thus capturing major global shocks such as the Asian and Russian crises, the early 2000s recession and the global financial crisis, as well as several waves of EU enlargement. The results of the estimation suggest that economies with a higher foreign bank ownership are more synchronized with the euro area. A greater foreign bank presence leads to stronger co-movement in output, being chiefly the result of greater alignment in investment cycles.

The authors believe that the positive relationship between foreign bank ownership and business cycle convergence reflects the functioning of the 25-year-old European Single Market. In many EU countries, high foreign bank ownership has been achieved due to cross-border capital flows from other EU member states. In other words, branches and subsidiaries of foreign banks were set up by banks whose home country usually belonged to the euro area. Such ownership patterns have been particularly strong in CEE countries that joined the EU in 2004 and later. Having operated under a similar legal framework for many years, foreign banks managed to build up strong relationships with their local clients. As the lending relationship developed, foreign banks treated the host countries more and more as an extension of their domestic market. As a corollary, strengthening the global business cycle and the rising incidence of global economic shocks did not lead to strong home country bias among foreign banks. Despite uncertainty stemming from possibly different regulatory and fiscal responses to shocks, their lending behaviour in home and host countries, especially in the corporate sector, was similar. That similarity fuelled cyclical convergence between the euro area and the economies remaining outside the common currency bloc.

The research results suggest that increasing foreign bank ownership boosts European monetary integration as a higher share of assets owned by foreign banks leads to the greater convergence of business cycles between EU member states and the euro area and thus lowers the costs of monetary integration. A common monetary policy is likely to be more appropriate for EU countries with a higher foreign bank ownership than for those which continue with domestic (including government) ownership. This conclusion, however, rests on the assumption that foreign banks originate mainly from other (primarily euro area) EU member states. Investigating whether the greater presence of non-EU foreign banks leads to the de-synchronization of business cycles between EU member states and the euro area remains a promising avenue for future research. 


\section{REFERENCES}

Aiyar, S., From financial crisis to great recession: The role of globalized banks, "The American Economic Review", 102(3), pp. 225-230, 2012.

Akerlof, G., Shiller, R., Animal spirits: how human psychology drives the economy, and why it matters for global capitalism. Princeton University Press, 2009.

André, C., Girouard, N. (2009), Housing Markets, Business Cycles and Economic Policies. Housing Market Challenges in Europe and the United States, pp. 109-130. Palgrave Macmillan UK, London 2004.

Arellano, M., Bover, O., Another look at the instrumental variable estimation of errorcomponents models, "Journal of Econometrics", 68(1), pp. 29-51, 1995.

Beck, T., Degryse, H., De Haas, R, Van Horen, N., When arm's length is too far. Relationship banking over the business cycle, "Journal of Financial Economics", 127(1), pp. 174-196, 2018.

Bernanke, B., Gertler, M., Gilchrist, S., The financial accelerator in a quantitative business cycle framework, "Handbook of Macroeconomics". Elsevier, 1999.

Bolton, P., Freixas, X., Gambacorta, L., Relationship and transaction lending in a crisis, "Review of Financial Studies", 29(10), pp. 2643-2676, 2016.

Bonin, J., Louie, D., Did foreign banks stay committed to emerging Europe during recent financial crises?, "Journal of Comparative Economics", 45, pp. 793-808, 2017.

Brzoza-Brzezina, M., Kolasa, M., Makarski, K., Crisis, contagion and international policy spillovers under foreign ownership of banks, "Journal of Financial Stability", 36(231), pp. 293-304, 2018.

Buch, C., Doepke, J., Pierdzioch, C., Financial openness and business cycle volatility, "Journal of International Money and Finance", 24(5), pp. 744-765, 2005.

Calderón, C., Chong, A., Stein, E., Trade intensity and business cycle synchronization: Are developing countries any different?, "Journal of International Economics", 71(1), pp. 2-21, 2007.

Calza, A., Monacelli, T., Stracca, L., Mortgage Markets, Collateral Constraints, and Monetary Policy: Do Institutional Factors Matter? Available at: https://papers.ssrn.com/sol3/ papers.cfm?abstract_id=1135471 (accessed: 24 January 2019), 2007.

Cardarelli, R., Monacelli, T., Rebucci, A., Sala, L., Housing Finance, Housing Shocks and the Business Cycle: Evidence from OECD Countries. Available at: https://www.bancaditalia.it/ pubblicazioni/altri-atti-seminari/2009/Cardarelli_Rebucci.pdf, 2009.

Catte, P., Girouard, N., Price, R., André, C., Housing Markets, Wealth and the Business Cycle. OECD Economic Department Working Papers, (394), pp. 4-42, 2004.

Cesa-Bianchi, A., Imbs, J., Saleheen, J., Finance and Synchronization. Bank of England Working Paper 612, 2016.

Cerqueira, P. A., Martins, R., Measuring the determinants of business cycle synchronization using a panel approach, "Economics Letters", 102(2), pp. 106-108, 2009.

Cetorelli, N., Goldberg, L. S. (2012a), Follow the money: Quantifying domestic effects of foreign bank shocks in the great recession, "The American Economic Review", 102(3), pp. 213-218, 2012a.

Cetorelli, N., Goldberg, L. S., Liquidity management of US global banks: Internal capital markets in the great recession, "Journal of International Economics", 88(2), pp. 299-311, $2012 b$. 
Cetorelli, N., Goldberg, L. S., Banking globalization and monetary transmission, "The Journal of Finance", 67(5), pp. 1811-1843, 2012c.

Chava, S., Purnanandam, A., The effect of banking crisis on bank-dependent borrowers, "Journal of Financial Economics", 99(1), pp. 116-135, 2011.

Choi, M. J., Gutierrez, E., Martinez Peria, M. S., Dissecting foreign bank lending behavior during the 2008-2009 crisis, "Financial Markets, Institutions and Instruments", 25(5), pp. 361-398, 2016.

Claessens, S., Kose, M., Terrones, M., What happens during recessions, crunches and busts?, "Economic Policy", 24(60), pp. 653-700, 2009.

Claessens, S., Van Horen, N., Being a foreigner among domestic banks: Asset or liability?, "Journal of Banking \& Finance", 36(5): pp. 1276-1290, 2012.

Cotis, J., Coppel, J., Business cycle dynamics in OECD countries: evidence, causes and policy implications. Reserve Bank of Australia Economic Conference. Available at: http://www. ems.bbk.ac.uk/for_students/msc_econ/ETA2_EMEC025P/OECD.pdf, 2005.

Cull, R., Soledad Martinez Peria, M., Verrier, J., Bank Ownership: Trends and Implications. IMF Working Paper 17/60, 2017.

Clark, T. E., van Wincoop, E. (2001), Borders and business cycles, "Journal of International Economics", 55, pp. 59-85, 2001.

Cuñat, A., Zymek, R., Specialization Patterns, GDP Correlations, and External Balances, "CESifo Economic Studies", 63(2), pp 141-161, 2017.

Czerniak, A., Rapacki, R., Emerging models of patchwork capitalism in Central and Eastern Europe: empirical results of subspace clustering, "International Journal of Management and Economics", 54(4), pp. 251-268, 2018.

Czerniak, A., Rubaszek, M., The Size of the Rental Market and Housing Market Fluctuations, “Open Economies Review”, 29(2), pp. 261-281, 2018.

Davis, M., Heathcote, J., Housing and the Business Cycle, "International Economic Review", 46(3), pp. 751-784, 2005.

De Haas, R., Korniyenko, Y., Pivovarsky, A., Tsankova, T., Taming the herd? Foreign banks, the Vienna Initiative and crisis transmission, "Journal of Financial Intermediation" 24(3), pp. 325-355, 2015.

De Haas, R., Van Lelyveld, I., Foreign banks and credit stability in Central and Eastern Europe. A panel data analysis, "Journal of Banking and Finance", 30(7), pp. 1927-1952, 2006.

De Haas, R., Van Lelyveld, I., Internal capital markets and lending by multinational bank subsidiaries, "Journal of Financial Intermediation", 19(1), pp 1-25, 2010.

De Haas, R, Van Lelyveld, I., Multinational banks and the global financial crisis: Weathering the perfect storm?, "Journal of Money, Credit and Banking", 46(1), pp. 333-364, 2014.

Demirgüç-Kunt, A., Levine, R., Min, H., Opening to Foreign Banks: Issues of Stability, Efficiency, and Growth [in:] Meltzer, A (ed.) The Implications of Globalization of World Financial Market, p. 83-105. Bank of Korea, 1998.

Detragiache, E., Gupta, P., Foreign banks in emerging market crises: Evidence from Malaysia, "Journal of Financial Stability", 2(3): 217-242, 2006.

Drazen, A., The Political Business Cycle after 25 Years, "NBER Macroeconomics Annual", 15, pp. 75-117. doi: 10.1086/654407, 2000. 
Duval, R., Li, N., Saraf, R., Seneviratne, D., Value-added trade and business cycle synchronization, "Journal of International Economics", 99, pp. 251-262, 2016.

European Banking Federation, https:/www.ebf.eu/facts-and-figures/structure-and-economiccontribution-of-the-banking-sector/, 2018.

European Systemic Risk Board, EU Shadow Banking Monitor No. 3 / September 2018. https://www.esrb.europa.eu/pub/pdf/reports/esrb.report180910_shadow_banking.en.pdf, 2018.

Fazzari, S., Ferri, P., Greenberg, E., Cash flow, investment, and Keynes-Minsky cycles, "Journal of Economic Behavior and Organization", 65(3-4), pp. 555-572, 2008.

Feldstein, M., Housing, Credit Markets and the Business Cycle, NBER Working Paper, pp. 1-13, 2007.

Fernández, A., Schmitt-Grohé, S., Uribe, M., World shocks, world prices, and business cycles: An empirical investigation, "Journal of International Economics", 108, pp. 2-14, 2017.

Fidrmuc, J., The Endogeneity of the Optimum Currency Area Criteria, Intra-industry Trade and EMU Enlargement. Bank of Finland Institute for Economies in Transition (BOFIT) Discussion Paper 8, 2001.

Frankel, J., Rose, A., The endogeneity of the optimum currency area criteria, "Economic Journal”, 108, pp. 1009-1025, 1998.

Fungáčová, Z., Herrala, R., Weill, L., The influence of bank ownership on credit supply: Evidence from the recent financial crisis, "Emerging Markets Review", 15, pp. 136-147, 2013.

Giovanni, J., Levchenko, A., Putting the Parts Together: Trade, Vertical Linkages, and Business Cycle Comovement, “American Economic Journal: Macroeconomics”, 2, pp. 95-124, 2010.

Gjerstad, S., Smith, V., Household Expenditure Cycles and Economic Cycles: Underlying Feedback Structures. ESI Working Papers. Available at: https://digitalcommons.chapman. edu/esi_working_papers/129, 2010.

Goldberg, L. S., Financial-sector foreign direct investment and host countries. New and old lessons. FRB of New York Staff Report 183, 2004.

Grauwe, P., Yuemei, J., The International Synchronisation of Business Cycles: the Role of Animal Spirits, "Open Economies Review”, 28(3), pp. 383-412, 2017.

Grubel, H. G., Lloyd, P. J., Intra-industry trade: The theory and measurement of international trade in differentiated products. Macmillian, London 1975.

Holland, A., Scott, A., The Determinants of UK Business Cycles, "The Economic Journal", 108(449), pp. 1067-1092, 1998.

Imbs, J., Trade, finance, specialization and synchronization, "Review of Economics and Statistics", 2004.

Imbs, J., The real effects of financial integration, "Journal of International Economics", 68 (2), 2006.

International Monetary Fund, Asset Prices and the Business Cycle, World Economic Outlook, pp. 77-112. Available at: https://www.imf.org/en/Publications/WEO/Issues/2016/12/31/ / media/Websites/IMF/imported-flagship-issues/external/pubs/ft/weo/2000/01/pdf/_chapter3 pdf.ashx, 2000.

Jeon, J. K., Trade intensity and business cycle synchronization, "Journal of Korea Trade", 22(1), pp. 36-49, 2018. 
Juvenal, L., Santos Monteiro, P., Trade and synchronization in a multi-country economy, "European Economic Review", 92, p. 385-415, 2017.

Kalecki, M., Capitalism, business cycles and full employment. Clarendon Press, 1990.

Karadimitropoulou, A., Advanced economies and emerging markets: Dissecting the drivers of business cycle synchronization, "Journal of Economic Dynamics and Control", 93, pp. 115-130, 2018.

Keynes, J. M., The General Theory of Output, Interest and Money, The Collected Writings of John Maynard Keynes, 1936.

Kose, M., Prasad, E., Terrones, M., How does globalization affect the synchronization of business cycles, "American Economic Review”, 93, pp. 57-62, 2003.

Kalemli-Ozcan, S., Papaioannou, E., Peydro, J. L., Financial Regulation, Financial Globalization, and the Synchronization of Economic Activity, "Journal of Finance" 68(3), pp. 1179-1228, 2013.

King, R., Plosser, C., Stock, J., Watson, M., Stochastic Trends and Economic Fluctuations. NBER Working Paper Series, Cambridge, MA, 1987.

Leamer, E., Housing really is the business cycle: What survives the lessons of 2008-09?, "Journal of Money, Credit and Banking", 47(S1), 2015.

Lee, C., Hsieh M., Dai, H., How Does Foreign Bank Ownership in the Banking Sector Affect Domestic Bank Behaviour? A Dynamic Panel Data Analysis, "Bulletin of Economic Research", 64, pp. 86-108, 2012.

Levine, R., Foreign Banks, Financial Development, and Economic Growth [in:] Barfield. C. E. (ed.), International Financial Markets: Harmonization versus Competition. The AEI Press, Washington, D.C., 1996.

Lumsdaine, R. L., Prasad, E. S., Identifying The Common Component Of International Economic Fluctuations: A New Approach, "Economic Journal”, 113(484), pp. 101-127, 2003.

Minsky, H., The Financial Instability Hypothesis, "Handbook of Radical Political Economy", (74), p. 9, 1992.

Montinari, L., Stracca, L., Trade, finance or policies: What drives the cross-border spill-over of business cycles?, "Journal of Macroeconomics", 49, p. 131-148, 2016.

Morgan, D., Rime, B., Strahan, P. E., (2004), Bank Integration and State Business Cycles, "The Quarterly Journal of Economics", 119(4), pp. 1555-1584, 2004.

Schnabl, P. (2012), The international transmission of bank liquidity shocks: Evidence from an emerging market, "The Journal of Finance", 67(3), pp. 897-932, 2012.

Zarnowitz, V. (1999), Theory and History behind Business Cycles: Are the 1990s the Onset of a Golden Age "The Journal of Economic Perspectives", 13(2), pp. 69-90, 1999.

Received: May 2018, revised: February 2019

Acknowledgement: This research was carried out under the project "Global financial crisis and evolution of theory of optimum currency areas in the context of the CEE countries' accession to the euro area", financed from Narodowe Centrum Nauki grant No. 2014/15/B/HS4/01038. 


\section{ANNEX}

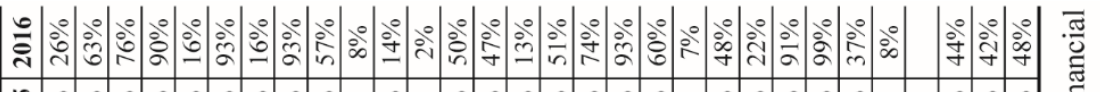

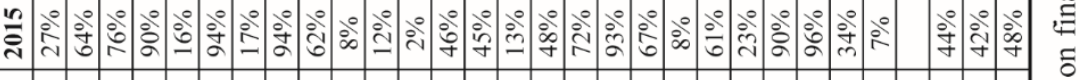

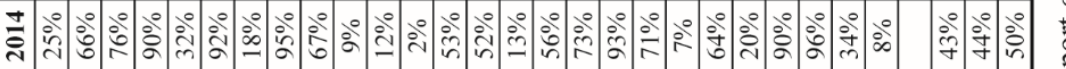

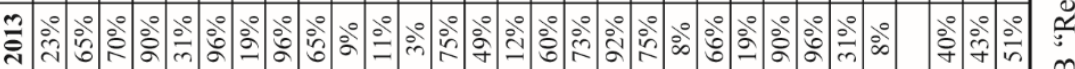
苛

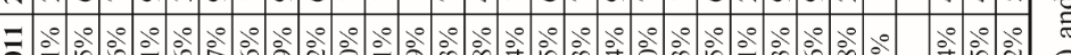

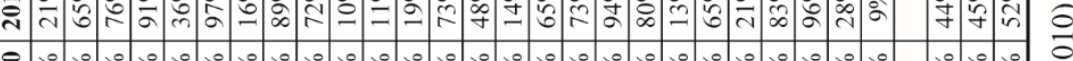

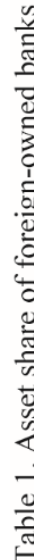
สิ่ง

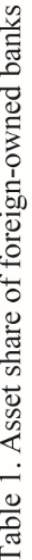

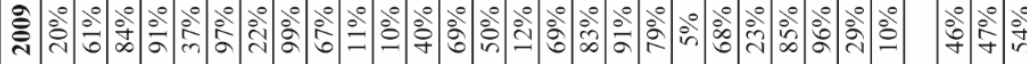

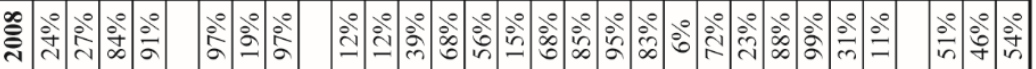

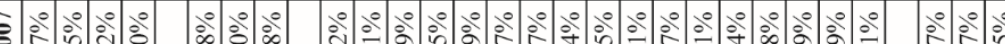

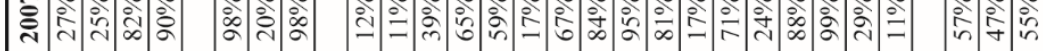

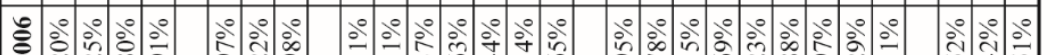

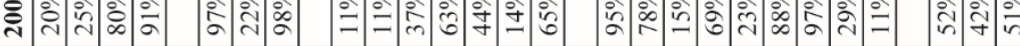

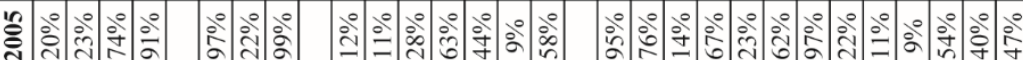

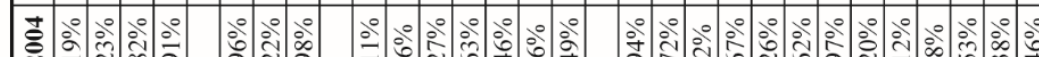

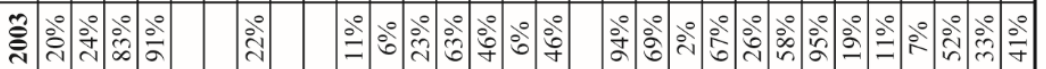

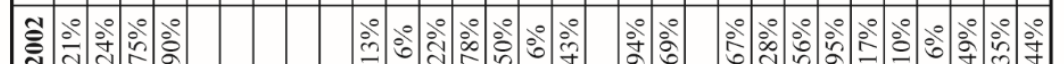

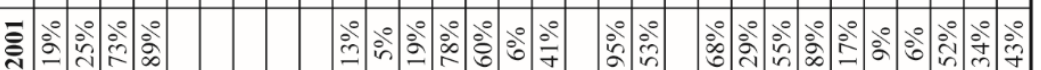

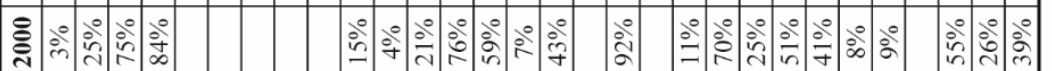

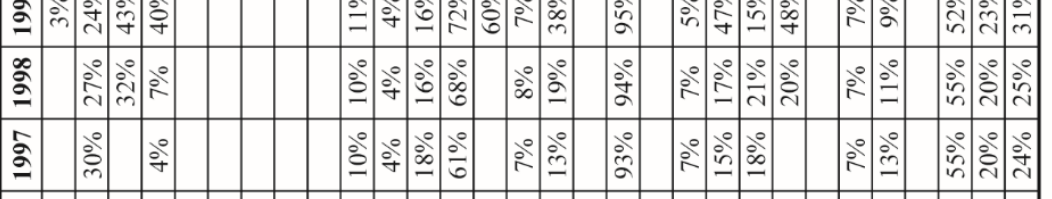




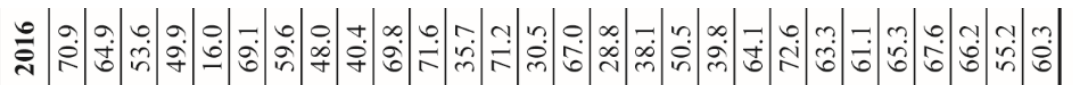

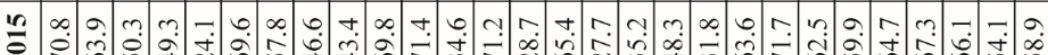

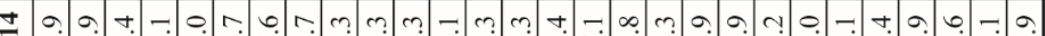
商

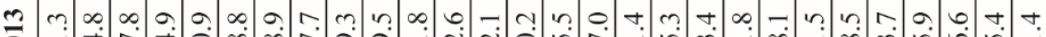

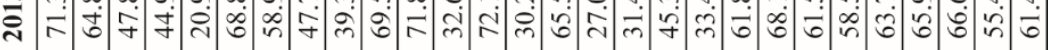
I $\infty$ ○. m. สิ)

Z

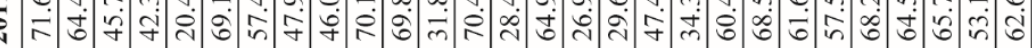

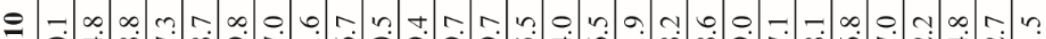
जิ ஓं

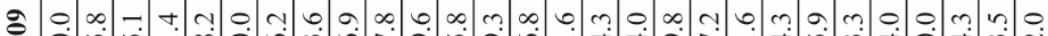
जे टं

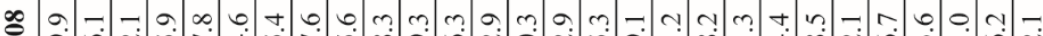

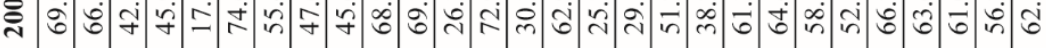
5 ก 0.0 . సิ शं

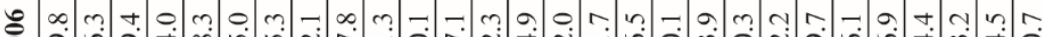

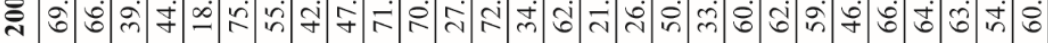
ย t. 商

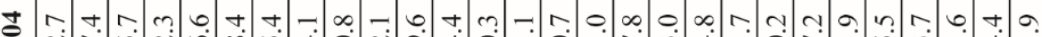

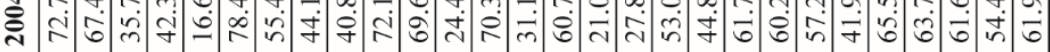

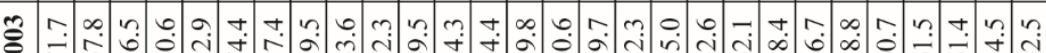
ปิ ิ

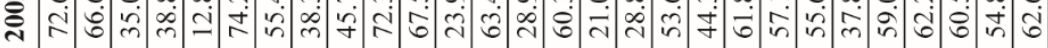

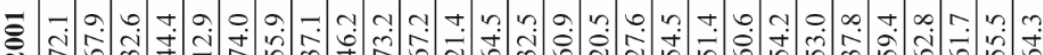

䱛

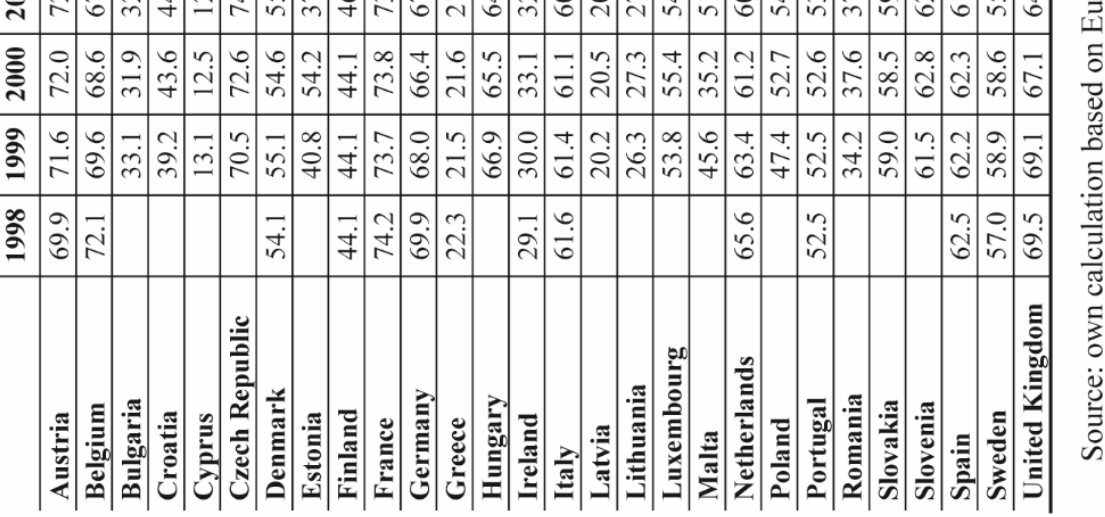




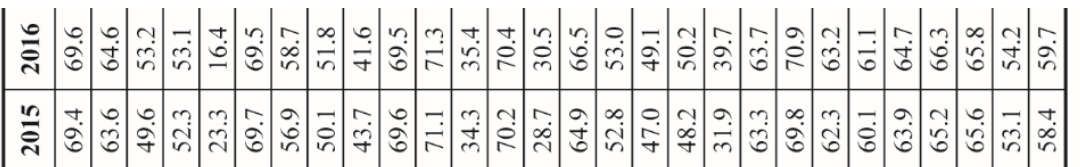

I

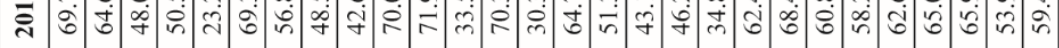

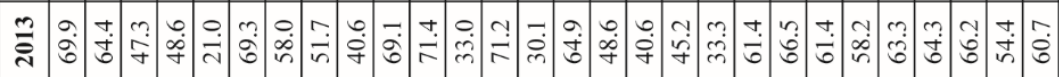

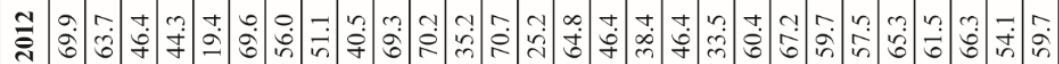

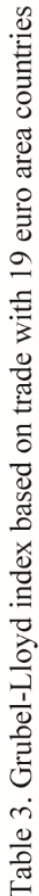

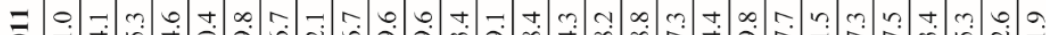

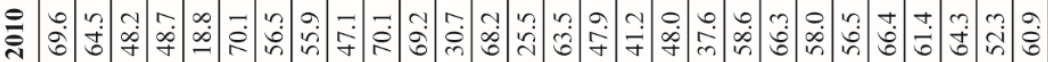

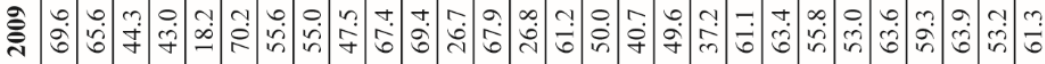

$\infty$ t. 0.0 .

जे

ร -

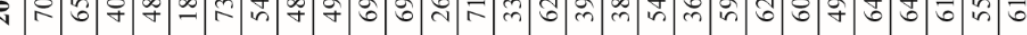

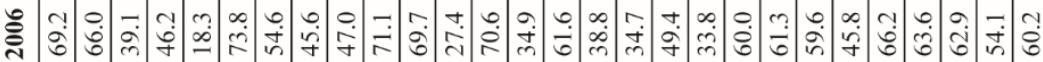

थ

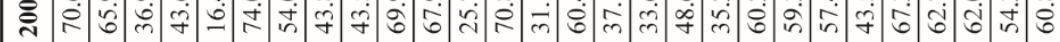

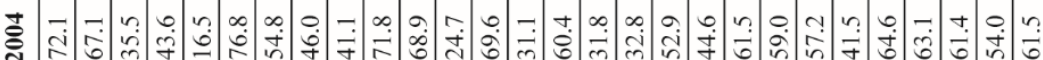

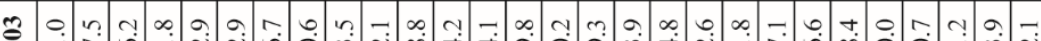

言

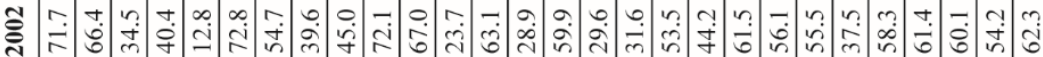

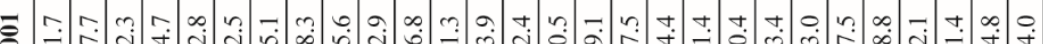

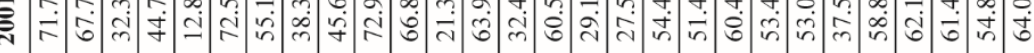

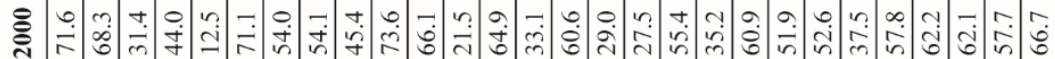

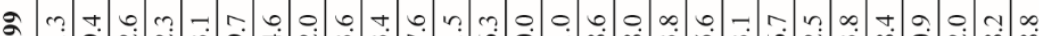

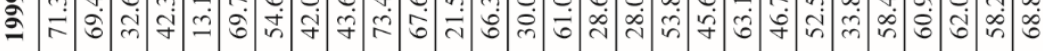

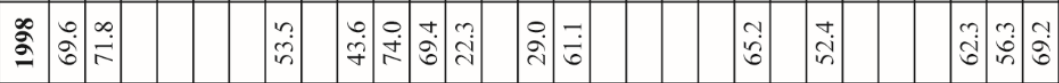

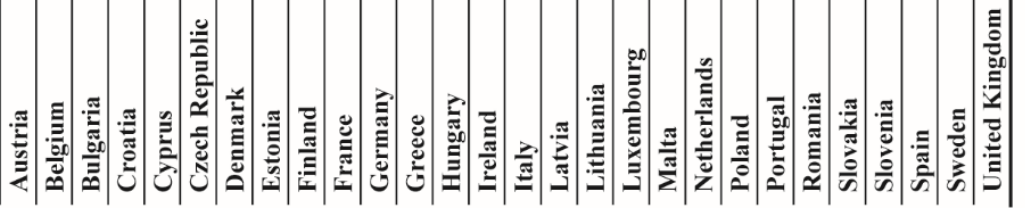


Table 4

Basic GMM estimation results with different control variables for GDP business cycle correlation with 12 euro area members

\begin{tabular}{|c|c|c|c|c|c|c|c|}
\hline & (1) & (2) & (3) & (4) & (5) & (6) & (7) \\
\hline $\begin{array}{l}\text { Lagged } \\
\text { dependent } \\
\text { variable }\end{array}$ & $0.493 * * *$ & $0.500 * * *$ & $0.499 * * *$ & $0.500 * * *$ & $0.503 * * *$ & $0.503 * * *$ & $0.490 * * *$ \\
\hline & $(0.0391)$ & $(0.0373)$ & $(0.0374)$ & $(0.0381)$ & $(0.0352)$ & $(0.0382)$ & $(0.0385)$ \\
\hline IIT & $0.00968^{*}$ & $0.00950^{*}$ & $0.00917^{*}$ & $0.0113^{* *}$ & $0.0117 * *$ & $0.0113 * * *$ & $0.0108^{* *}$ \\
\hline & $(0.00512)$ & $(0.00533)$ & $(0.00536)$ & $(0.00473)$ & $(0.00536)$ & $(0.00414)$ & $(0.00548)$ \\
\hline ownership & $0.434 * * *$ & $0.388^{* *}$ & $0.409^{* *}$ & $0.434 * * *$ & 0.253 & $0.287^{*}$ & $0.422 * *$ \\
\hline & $(0.159)$ & $(0.153)$ & $(0.163)$ & $(0.155)$ & $(0.189)$ & $(0.161)$ & $(0.174)$ \\
\hline $\mathrm{TS}$ & -0.00541 & & $-0.00573^{*}$ & $-0.00492 *$ & $-0.00579 *$ & $-0.00567^{*}$ & $-0.00693 * *$ \\
\hline & $(0.00332)$ & & $(0.00346)$ & $(0.00293)$ & $(0.00303)$ & $(0.00310)$ & $(0.00289)$ \\
\hline $\mathrm{ES}$ & & -0.00789 & & & & & \\
\hline & & $(0.00509)$ & & & & & \\
\hline & \multicolumn{7}{|c|}{ Predetermined variables in the GMM estimation } \\
\hline & \multicolumn{7}{|c|}{ Statistically significant control variables } \\
\hline \multirow[t]{2}{*}{ Conv } & $0.578 * *$ & $0.575^{* * *}$ & $0.586^{* *}$ & $0.554 * *$ & $0.650 * * *$ & 0.0389 & $0.666^{* * *}$ \\
\hline & $(0.230)$ & $(0.201)$ & $(0.246)$ & $(0.245)$ & $(0.167)$ & $(0.219)$ & $(0.184)$ \\
\hline \multirow[t]{3}{*}{ PIL } & $-0.0102 * * *$ & $-0.0105^{* * *}$ & $-0.0101 * * *$ & $-0.0098 * * *$ & $-0.0105^{* * *}$ & 0.00188 & $-0.0114 * * *$ \\
\hline & $(0.00373)$ & $(0.00332)$ & $(0.00387)$ & $(0.00362)$ & $(0.00297)$ & $(0.00406)$ & $(0.00316)$ \\
\hline & \multicolumn{7}{|c|}{ Other control variables } \\
\hline \multirow[t]{2}{*}{ E_union } & & & 0.0406 & & & & \\
\hline & & & $(0.0804)$ & & & & \\
\hline \multirow[t]{2}{*}{ eurozone } & & & & 0.00466 & & & \\
\hline & & & & $(0.0995)$ & & & \\
\hline \multirow[t]{2}{*}{ Share } & & & & & -1.545 & & \\
\hline & & & & & $(1.279)$ & & \\
\hline \multirow[t]{2}{*}{ Spec } & & & & & & -0.159 & \\
\hline & & & & & & (1.058) & \\
\hline \multirow[t]{2}{*}{ market_b } & & & & & & & -0.244 \\
\hline & & & & & & & $(0.202)$ \\
\hline \multirow[t]{2}{*}{ Constant } & 0.0696 & 0.0287 & 0.0845 & -0.0559 & 0.154 & -0.179 & 0.163 \\
\hline & $(0.369)$ & $(0.363)$ & $(0.363)$ & $(0.362)$ & $(0.319)$ & $(0.280)$ & $(0.344)$ \\
\hline $\begin{array}{l}\text { Number of } \\
\text { observations }\end{array}$ & 386 & 386 & 386 & 386 & 386 & 357 & 386 \\
\hline $\begin{array}{l}\text { Number of } \\
\text { countries }\end{array}$ & 28 & 28 & 28 & 28 & 28 & 28 & 28 \\
\hline $\begin{array}{l}\text { Wald } \\
\text { statistics }\end{array}$ & 329.1 & 305.5 & 424.9 & 374 & 325.3 & 422.6 & 365.9 \\
\hline
\end{tabular}

Note: Robust standard errors in parentheses $* * * \mathrm{p}<0.01,{ }^{* *} \mathrm{p}<0.05,{ }^{*} \mathrm{p}<0.1$

Source: own calculation. 


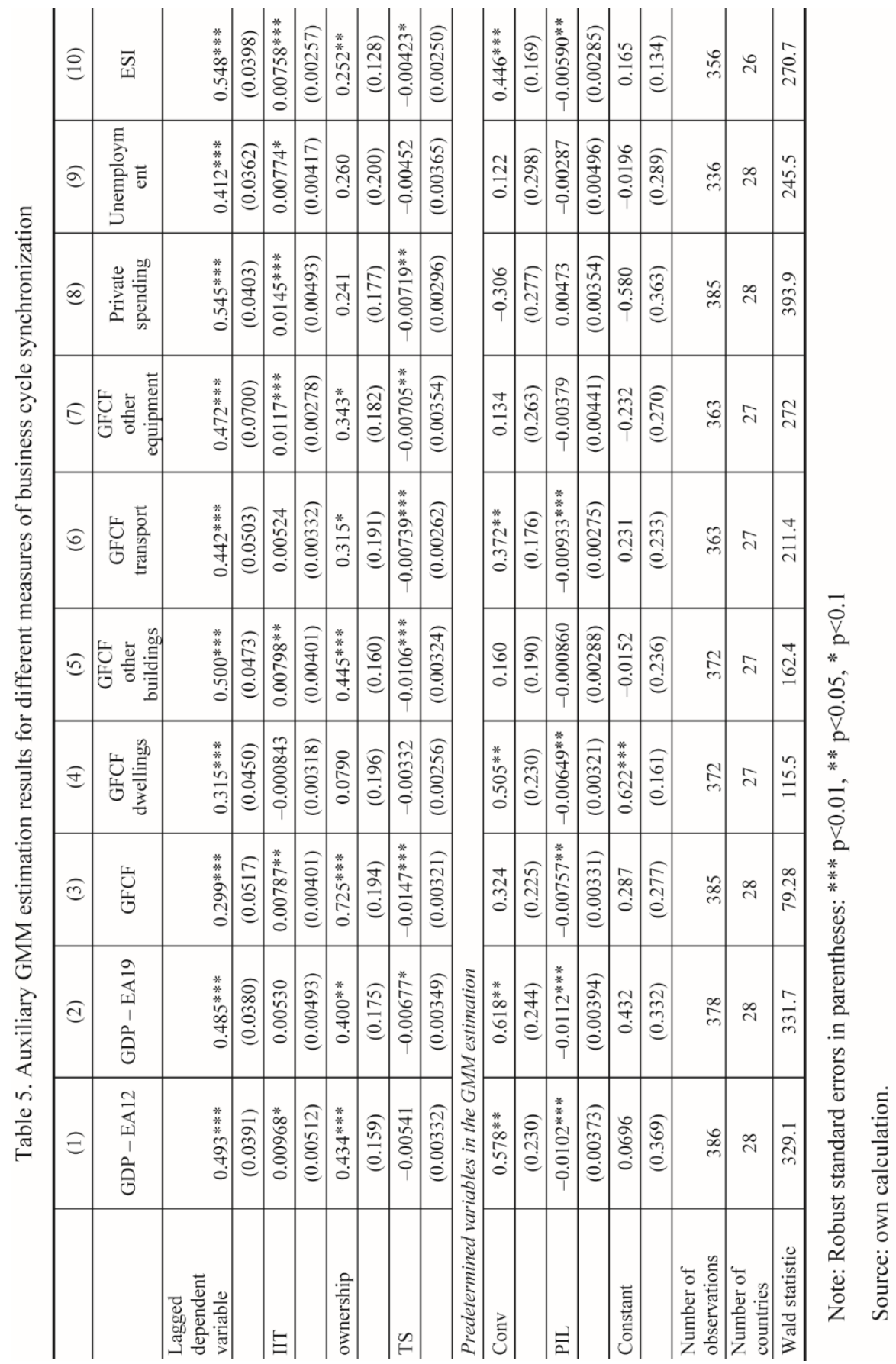

